\title{
Anthropometric and biochemical assessment of nutritional status and dietary intake in school children aged 6-14 years, Province of Buenos Aires, Argentina
}

\author{
Lorena Lázaro Cuesta, B.S. ${ }^{a}$, Analía Rearte, M.D. ${ }^{a}$, Sergio Rodríguez, M.D. ${ }^{a}$, \\ Melina Niglia, B.S. ${ }^{a}$, Horacio Scipioni, B.S. ${ }^{a}$, Diego Rodríguez, Biochemist ${ }^{a}$, \\ Rosalía Salinas, B.S. ${ }^{a}$, Claudia Sosa ${ }^{a}$ and Stella Rasse, M.D. ${ }^{a}$
}

\begin{abstract}
Introduction: Childhood obesity is a global epidemic. School age and adolescence are critical stages for the implementation of eating and lifestyle habits.

Objective: To assess anthropometric and biochemical assessment of nutritional status and dietary intake in children, their relationship with socioeconomic factors and georeferencing. Methods: Cross-sectional study in schoolchildren aged 6-14 years from the District of General Pueyrredón, during August-November 2013. Dietary intake was assessed using a 24-hour dietary recall interview, and georeferencing was done using the gvSIG software.
\end{abstract}

Results: A total of 1296 children wereincluded for anthropometric and socioeconomic assessment. A sub-sample included 362 children for intake and biochemical parameters. Overweight was observed in $42.97 \%$ ( $95 \%$ confidenceinterval [CI]: 40.3-45.7) and obesity, in 18.5\% (95\% CI: $16.3-$ 20.5). Breakfast was related to a lower risk for overweight (OR: 0.7, 95\% CI: 0.5-0.9) and obesity (OR: 0.7, 95\% CI: 0.5-0.9). Attending high school was related to a lower prevalence of weight excess (OR: 0.45, 95\% CI: 0.3-0.7); male sex posed a higher risk for obesity (OR: 1.7, 95\% CI: 1.3-2.3). Also, $4.44 \%$ of participants had anemia; $19.6 \%$, hypercholesterolemia; and $21.3 \%$, hypertriglyceridemia. Lipid and saturated fat intake was high, whereas dietary cholesterol and fiber intake was low. Geographic distribution was homogeneous.

Conclusions: The prevalence of overweight was high. The risk for obesity was higher among boys; breakfast appeared as a protective factor against overweight/obesity. A low-fiber and high-fat intake, and high blood cholesterol and triglyceride levels reveal that overnutrition is a prevalent public health problem.

Key words: nutritional status, obesity, overweight, child nutrition, adolescent nutrition.

http:/ / dx.doi.org/10.5546/ aap.2018.eng.e34

To cite: Lázaro Cuesta L, Rearte A, Rodríguez S, et al. Anthropometric and biochemical assessment of nutritional status, and dietary intake in schoolchildren aged 6-14 years, Province of Buenos Aires, Argentina. Arch Argent Pediatr 2018;116(1):e34-e46.

\section{INTRODUCTION}

In the past three decades, childhood obesity has become a global epidemic. ${ }^{1-3}$ School age and adolescence are critical stages for shaping eating and lifestyle habits that will last later in life and have an effect during adulthood and even old age. ${ }^{4}$

Vitamin A deficiency is a health problem worldwide, especially in developing countries. Iron and zinc are relevant nutrients for an adequate growth and development. ${ }^{5}$ The most common forms of childhood malnutrition are specific micronutrient deficiencies that may not be diagnosed using an anthropometry. ${ }^{6}$ Such deficiencies affect learning, growth, and development in children. ${ }^{5}$

At present, Latin America is going through a nutritional transition and for this reason malnutrition coexists with overweight, obesity, and micronutrient deficiencies. ${ }^{7}$ In Argentina, the most recent studies have demonstrated that at least $3 / 10$ children or adolescents are overweight, ${ }^{8-10}$ and this prevalence has increased steadily in the past years, as in the rest of the world. ${ }^{11}$ Most studies on nutritional status have focused on preschoolers and adolescents, so our objective was to make an anthropometric and biochemical assessment of nutritional status and dietary intake in schoolchildren aged 6-14 years from the District of General Pueyrredón, their relationship with socioeconomic factors and to implement georeferencing based on children's place of residence. 


\section{POPULATION AND METHODS}

Descriptive, analytical, cross-sectional study conducted between August and November 2013 in the District of General Pueyrredón (Province of Buenos Aires [PBA]), a town of 618989 inhabitants, of whom 81911 were aged 6-14 years (13.23\%). ${ }^{12}$ In 2013, the District of General Pueyrredón had 323 schools. The rate of school enrollment was 94\% in 2006.

The sample included schoolchildren aged 6-14 years. Participants selected for the subsample were asked to fast for 12 hours. Children with chronic conditions and primary or secondary immunosuppression were excluded.

The sample size estimated for the anthropometric assessment was 1197 students, considering the less prevalent event (wasting: $1.4 \%),{ }^{8}$ and a $95 \%$ confidence level. The District of General Pueyrredón was divided into three areas; the eight divisions of the school district were grouped and 22 schools were randomly selected, respecting the percentage of public and private schools $(60 \% / 40 \%$, respectively) and the proportion of each age group. Grades were also randomly sampled.

A sub-sample was selected to assess dietary intake and biochemical parameters. The subsample size was estimated at 300 children, considering a $25 \%$ event prevalence (anemia), and a 95\% confidence level..$^{13}$ Five or six children were randomly selected from each grade for this estimation.

Socioeconomic data were collected using a specially designed questionnaire, which was completed by parents under the supervision of trained staff (see Annex 1).

Anthropometric data were collected at each school by trained staff (see Annex 2). Weight was measured using CAM portable scales, P-1001PCADOBLE code. Height was measured using a non-extensible tape measure in a vertical plane and on a hard surface as horizontal plane. Measuring techniques were based on the Growth and Development Guidelines of the Argentine Society of Pediatrics. ${ }^{14}$ Waist circumference was measured at the upper edge of the iliac crest using the cross-handed technique and a Lufkin-like metal tape. References from J. R. Fernández et al. were used assuming a cut-off point in the $90^{\text {th }}$ percentile. ${ }^{15}$ Two measurements were made and the average was estimated.

Lab samples were taken by trained nurses and processed within 3 hours of collection. Ethylenediaminetetraacetic acid (EDTA) tubes were used (hemoglobin and hematocrit) and a tube without anticoagulant for the rest of the lab tests.

Samples were analyzed at the lab of Hospital Interzonal Especializado Materno Infantil (HIEMI). Vitamin A, zinc, and folate were studied at the lab of the Pediatric Research and Development Institute (Instituto de Desarrollo e Investigaciones Pediátricas [IDIP]) "Prof. F. E. Viteri," Hospital de Niños "Sor María Ludovica," La Plata.

For collecting data on intake, 11 nutritionists were trained on standardized methodology and used a 24-hour recall interview, visual aids, and food fact sheets. ${ }^{16,17}$ The proportion of week days, weekends or holidays was established to assess intake.

Two teams made up of 10 people were available (nurses, nutritionists, physicians, promoters, and social workers). Two schools were assessed each week, and 3 weekly visits were made to each school. Feedback was provided to each schoolchild. Participants with nutritional alterations were contacted for a referral to the Department of Pediatrics.

The following sociodemographic outcome measures were included: sex, age, maternal level of education, health coverage, private/public school, primary/secondary education, number of daily meals, and breakfast, lunch, and dinner habits $\geq 4$ times per week.

Anthropometric outcome measures: child growth standards and classification published by the World Health Organization (WHO).$^{18}$

Nutritional status (body mass index [BMI]) $)^{15,19}$ was classified into very low weight: $\leq-3$ standard deviations (SDs); low weight: $\leq-2$ SDs / > -3 SDs; normal weight: $>-2$ SDs $/<+1$ SD; overweight: $\geq+1$ SD / <+2 SDs; obesity: $\geq+2$ SDs / < +3 SDs; severe obesity: $\geq+3$ SDs. Overweight, obesity, and severe obesity were considered excess weight. Waist circumference (WC) was considered normal if $<90^{\text {th }}$ percentile and increased if $\geq 90^{\text {th }}$ percentile.

Biochemical outcome measures were estimated: hematocrit and hemoglobin (low: $<-2$ SDs of the mean for age and sex as an anemia indicator), lipid profile, prealbumin (nephelometry), ferritin (chemiluminescence), vitamin A, zinc (flame atomic absorption spectroscopy, $213.9 \mathrm{~nm}$ ), and folate.

Calorie, protein, fat, cholesterol, carbohydrate, fiber, vitamin A, calcium, iron, zinc, and folate intake was assessed. 

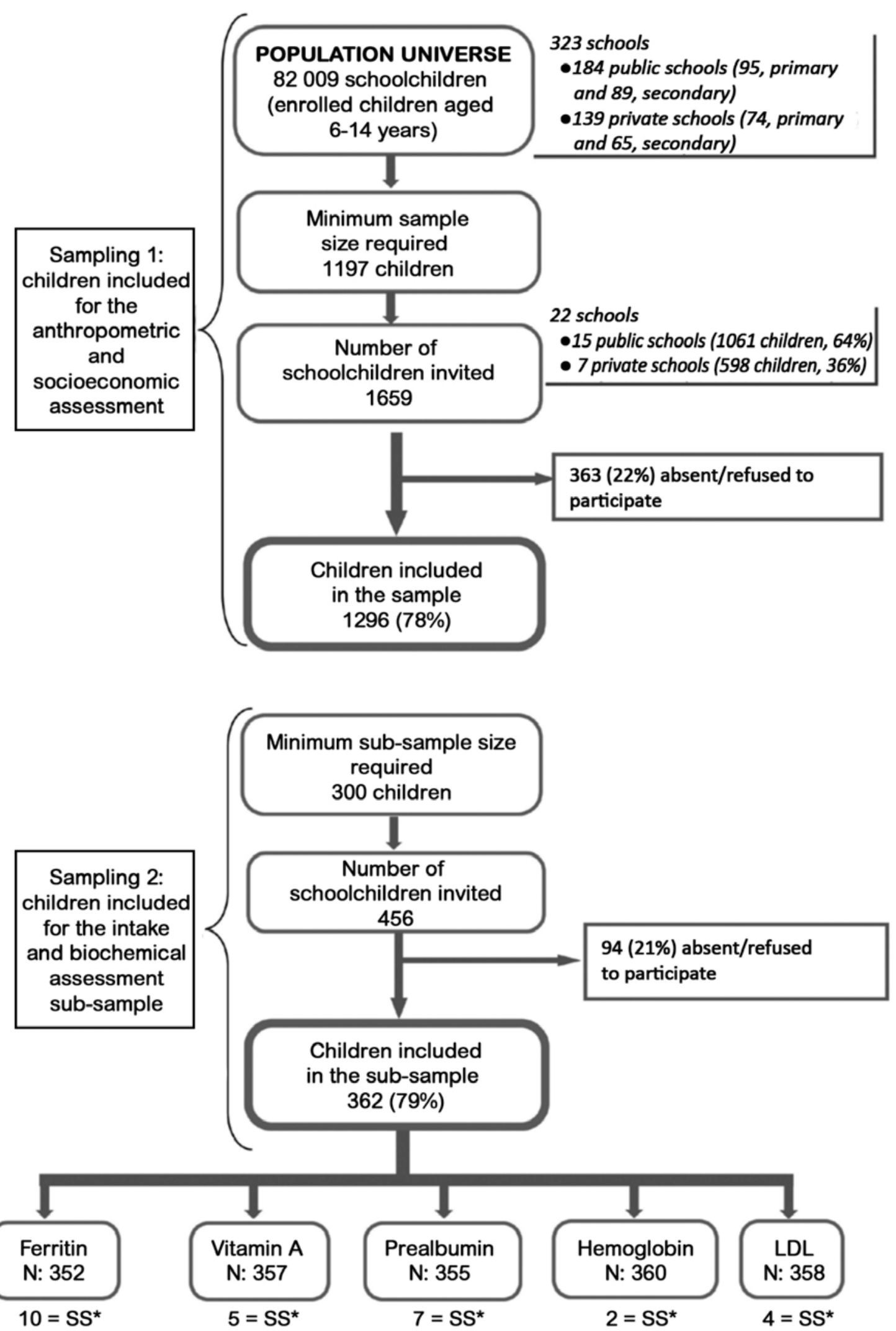

*SS: scant specimen. 
Trans fat intake was estimated by difference from total fat as a percentage of the median energy intake.

Ethical considerations: the study was approved by the Bioethics Committee of HIEMI and the Joint Commission of Health Research of the Ministry of Health of the PBA.

A signed informed consent was obtained from parents or guardians, together with schoolchildren's assent.

\section{Statistical analysis}

The following software programs were used: the WHO Anthro Plus for the anthropometry, the SARA (analysis system and food registry) for intake, and the Epi Info 7 for the statistical analysis.

Median and interquartile range or mean and standard deviation (SD) were estimated for continuous outcome measures, and proportions were calculated for categorical data with 95\% confidence intervals (CI). The $t$ test or the Wilcoxon rank-sum test was used for continuous data, and the $\chi^{2}$ test, for proportions. A multivariate analysis was done using a multiple logistic regression model and outcome measures associated with overweight and obesity were assessed. The odds ratio (OR) with a 95\% CI was used as a measure of association. An alpha error of $5 \%$ was considered acceptable.

For intake, the median nutrient value, calorie intake, and percentage of macronutrients from total caloric intake (TCI) were estimated. Results were compared to the dietary reference intake (DRI). ${ }^{20}$

For georeferencing, the gvSIG software was used to manage geographic information with mapping accuracy, which helped to visualize the sample distribution. No statistical tests were used.

\section{RESULTS}

The anthropometric assessment and the survey were completed in 1296 schoolchildren from 70 grades of 22 schools; 362 had a blood sample taken (Figure 1).

Table 1 describes the characteristics of the population.

\section{Anthropometry}

Excess weight was observed in $43 \%$ of children (95\% CI: 40.3-45.7) (Figure 2).

Increased WC was observed in $19.1 \%$ (95\% CI: 16.91-21.19). The proportion varied by

TABLE 1. Description of the population, $n=1296$

\begin{tabular}{|c|c|c|c|c|c|c|c|}
\hline $\begin{array}{l}\text { Outcome } \\
\text { measure }\end{array}$ & Frequency $(\%)$ & $\begin{array}{l}\text { Overweight } \\
\text { percentage }\end{array}$ & $p$ & $\begin{array}{c}\text { Obesity } \\
\text { percentage }\end{array}$ & $p$ & $\begin{array}{c}\text { Excess weight } \\
\text { percentage } \\
\text { (overweight }+ \text { obesity) }\end{array}$ & ) \\
\hline $\begin{array}{l}\text { Age group } \\
\text { 6-8 years old } \\
\text { 9-14 years old }\end{array}$ & $\begin{array}{l}387(29.8) \\
909(70.1)\end{array}$ & $\begin{array}{c}23 \\
25.2\end{array}$ & 0.4 & $\begin{array}{l}18.4 \\
18.5\end{array}$ & 0.9 & $\begin{array}{l}41.3 \\
43.7\end{array}$ & 0.4 \\
\hline $\begin{array}{l}\text { Type of school } \\
\text { Public } \\
\text { Private }\end{array}$ & $\begin{array}{c}818(63.1) \\
478(35)\end{array}$ & $\begin{array}{l}23.6 \\
26.2\end{array}$ & 0.3 & $\begin{array}{l}19.9 \\
15.9\end{array}$ & 0.07 & $\begin{array}{l}43.5 \\
42.1\end{array}$ & 0.6 \\
\hline $\begin{array}{l}\text { Sex } \\
\text { Male } \\
\text { Female }\end{array}$ & $\begin{array}{l}627(48.4) \\
669(51.6)\end{array}$ & $\begin{array}{l}23 \\
26\end{array}$ & 0.2 & $\begin{array}{l}22.3 \\
14.8\end{array}$ & 0.0004 & $\begin{array}{l}45.3 \\
40.8\end{array}$ & 0.1 \\
\hline $\begin{array}{l}\text { Level of education } \\
\text { Primary } \\
\text { Secondary }\end{array}$ & $\begin{array}{l}998(77) \\
298(23)\end{array}$ & $\begin{array}{l}25.9 \\
19.8\end{array}$ & 0.03 & $\begin{array}{l}19.6 \\
14.3\end{array}$ & 0.04 & $\begin{array}{l}45.6 \\
34.2\end{array}$ & 0.0005 \\
\hline $\begin{array}{l}\text { Living with children }<5 \text { years old } \\
\text { No } \\
\text { Yes }\end{array}$ & $\begin{array}{c}1219(95.5) \\
58(4.5)\end{array}$ & $\begin{array}{l}24.9 \\
17.2\end{array}$ & 0.2 & $\begin{array}{l}18.3 \\
24.1\end{array}$ & 0.3 & $\begin{array}{l}43.2 \\
41.4\end{array}$ & 0.8 \\
\hline $\begin{array}{l}\text { Maternal level of education } \\
\text { Incomplete secondary education } \\
\text { Complete secondary } \\
\text { or higher education }\end{array}$ & $635(49)$ & 25 & 0.6 & $\begin{array}{l}19.4 \\
17.6\end{array}$ & 0.4 & $\begin{array}{l}44.4 \\
41.6\end{array}$ & 0.3 \\
\hline $\begin{array}{l}\text { Health coverage } \\
\text { Social insurance or } \\
\text { managed care organization } \\
\text { Public sector }\end{array}$ & $\begin{array}{l}780(60.8) \\
501(39.1)\end{array}$ & $\begin{array}{c}24.9 \\
24\end{array}$ & 0.2 & $\begin{array}{c}18.5 \\
19\end{array}$ & 0.9 & $\begin{array}{l}43.3 \\
42.9\end{array}$ & 0.5 \\
\hline $\begin{array}{l}\text { Breakfast } \\
\text { Yes } \\
\text { No }\end{array}$ & $\begin{array}{c}1044(81.6) \\
235(18.4)\end{array}$ & $\begin{array}{c}24 \\
26.4\end{array}$ & 0.5 & $\begin{array}{c}17.7 \\
23\end{array}$ & 0.06 & $\begin{array}{l}41.8 \\
49.4\end{array}$ & 0.03 \\
\hline
\end{tabular}


nutritional status and was 78.2\% (95\% CI: 71.983.6) among obese children, $100 \%$ (95\% CI: 73.54$100)$ among severely obese children, $15.8 \%$ (95\% CI: 12.2-20.2) among overweight children, and $0.28 \%$ (95\% CI: 0.08-1) among those with a normal weight.

As regards eating habits, 76.84\% (95\% CI: 74.579.1) of children had 4 daily meals; $97.7 \%$ (95\% CI: 96.8-98.4), 2 meals; and 0.39\% (95\% CI: 0.2-0.9), only 1 meal.

\section{Multivariate analysis}

Two multivariate analysis models were developed to assess associated outcome measures due to: a) excess weight (overweight + obesity) and b) obesity. Age, maternal level of education, number of household members, health coverage, type of school or lunch and dinner habits were not associated with excess weight or obesity.

Breakfast was related to a lower risk for overweight (OR: 0.7, 95\% CI: 0.5-0.9) and obesity (OR: 0.7, 95\% CI: 0.5-0.9). Attending high school was associated with a lower prevalence of excess weight (OR: 0.45, 95\% CI: 0.3-0.7). Male sex was related to a higher risk for obesity (OR: 1.7, 95\% CI: 1.3-2.3).

\section{Lab tests}

The sociodemographic characteristics of the sub-sample showed no significant differences with the overall sample, so it was representative of it. The percentage of obese children was 18.5\%
(95\% CI: 14.9-22.8) and of children with excess weight, $41.2 \%$ (95\% CI: 36.2-46.3).

Besides, $100 \%$ of assessed children had normal zinc and folic acid levels; 2 children had vitamin A deficiency; 3, low ferritin levels; and 2, low prealbumin levels.

Anemia was observed in 16 children $(4.4 \%$, 95\% CI: 2.7-7.1); 13 boys and 3 girls (OR: $4.6,95 \%$ CI: $1.3-16.4, p: 0.01)$. Ten of these children were in the 12-14-year-old group and 14 had a normal weight for their age.

Table 2 shows the results of the biochemical determination of lipid profile.

TABLE 2. Results of biochemical determinations of lipid profile, $n=362$

\begin{tabular}{llccc}
\hline \multicolumn{2}{l}{ Outcome measure } & Percentage & \multicolumn{2}{c}{ 95\% CI } \\
\hline Cholesterol & High & 3.9 & 2.2 & 6.6 \\
& Borderline & 15.8 & 12.2 & 20.0 \\
\multirow{4}{*}{ LDL } & Normal & 80.4 & 75.8 & 84.3 \\
& High & 9.8 & 7.1 & 13.3 \\
HDL & Normal & 90.2 & 86.7 & 92.9 \\
\multirow{4}{*}{ Triglycerides } & Low & 8.8 & 6.3 & 12.2 \\
& Normal & 91.2 & 87.8 & 93.7 \\
& High & 21.3 & 17.2 & 25.9 \\
& Low & 14.1 & 10.8 & 18.2 \\
& Normal & 64.6 & 59.4 & 69.5 \\
\hline
\end{tabular}

CI: confidence interval; LDL: low density lipoproteins; HDL: high density lipoproteins.

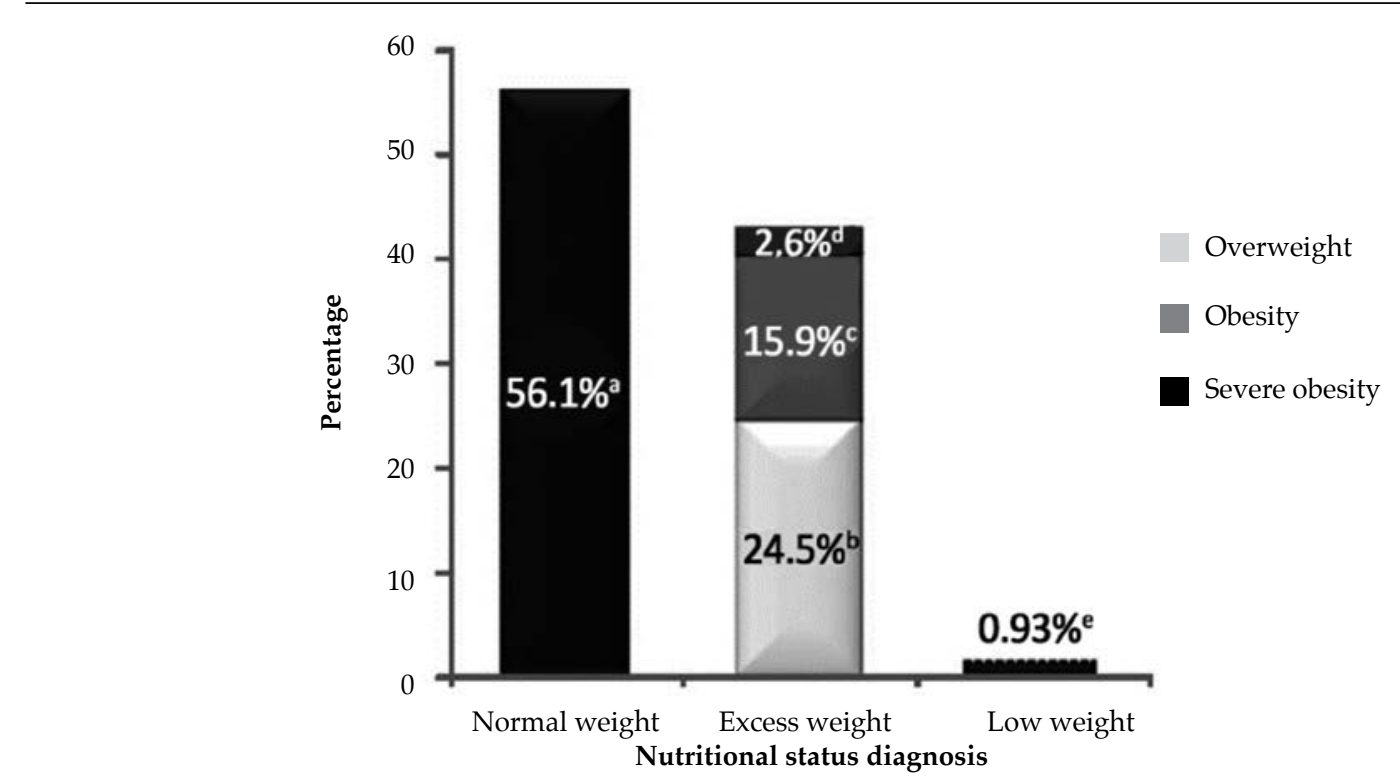

${ }^{a}\left(95 \%\right.$ CI: 53.4-58.8); ${ }^{\text {b }}$ (95\% CI: 22.1-26.8); ${ }^{\mathrm{c}}$ (95\% CI: 13.9-17.9); ${ }^{\mathrm{d}}$ (95\% CI: 1.7-3.5); ${ }^{\mathrm{e}}$ (95\% CI: 0.9-3.9) 
High cholesterol levels were detected in $19.6 \%$ of children, ranging from $25.5 \%$ among obese children to $17.5 \%$ among normal weight children. Such difference was not significant.

High triglyceride levels were found in $21.3 \%$. This percentage ranged from $30.2 \%$ (95\% CI: 23.4-30.7) among children with excess weight to $15.02 \%$ (95\% CI:10.2-20.1) among those with a normal weight (OR: 2.4; 95\% CI: 1.5-4.1, $p<0.001$ ).

Among children with excess weight, obese children had a higher prevalence of high triglyceride levels (overweight: $21.95 \%$, obese: $40 \%$, severely obese: $41.67 \%$ ); when non-obese children were compared to obese ones, the latter had more than a threefold risk for high triglyceride levels than non-obese children (OR: 3.3, 95\% CI: 1.86-5.9, $p<0.001$ ).

\section{Intake}

The median daily intake of energy was $2136 \mathrm{kcal}$. The median percentage of proteins compared to the TCI was 13.2\%; of carbohydrates, $51.6 \%$, and of lipids, $35.5 \%$ (Table 3). The median percentage of lipids compared to the TCI was higher than recommended $(<10 \%)$, as well as the saturated fat intake, whereas dietary cholesterol and fiber intake was lower than recommended. Trans fat intake accounted for approximately $2.69 \%$ of the TCI, higher than recommended $(1 \%)$.

\section{Georeferencing}

Children distribution was homogeneous across the District of General Pueyrredón in terms of both biochemical and anthropometric parameters. No predominant areas were observed for none of the studied outcome measures (see Annex 3).

\section{DISCUSSION}

The results of this study showed a high prevalence of children with excess weight, even higher than that observed in other national studies. $8,9,10$ These results were expected and reflect the growing trend of overweight and obesity and the size of the problem in the selected age group.

The WHO technical report "Diet, nutrition and the prevention of chronic diseases: Report of a joint WHO/FAO expert consultation" described this as an increasingly prevalent public health problem that requires to be addressed by means of a comprehensive strategy. For this reason, the recommendation is to prevent obesity in children and adolescents through the promotion of an active lifestyle, fruit and vegetable consumption, a reduction in screen time, and a restriction of sugar-sweetened beverages and salt. ${ }^{21}$

Among the socioeconomic outcome measures included in the multivariate models, male sex

TABLE 3. Calorie intake by sex and age. Comparison to the dietary reference intake*

\begin{tabular}{|c|c|c|c|c|c|c|c|c|c|c|c|c|}
\hline \multirow{4}{*}{ Nutrient } & \multicolumn{6}{|c|}{ 6-8 years old } & \multicolumn{6}{|c|}{ 9-14 years old } \\
\hline & \multicolumn{3}{|c|}{ Girls } & \multicolumn{3}{|c|}{ Boys } & \multicolumn{3}{|c|}{ Girls } & \multicolumn{3}{|c|}{ Boys } \\
\hline & \multirow[t]{2}{*}{ DRI } & \multicolumn{2}{|c|}{ Percentile } & \multirow[t]{2}{*}{ DRI } & \multicolumn{2}{|c|}{ Percentile } & \multirow[t]{2}{*}{ DRI } & \multicolumn{2}{|c|}{ Percentile } & \multirow[t]{2}{*}{ DRI } & \multicolumn{2}{|c|}{ Percentile } \\
\hline & & 50 & $25-75$ & & 50 & $25-75$ & & 50 & $25-75$ & & 50 & $25-75$ \\
\hline Energy $24 \mathrm{~h}$ calories / day (kcal) & 1519 & 2024 & $1722-2315$ & 1614 & 2075 & $1548-2404$ & 1856 & 1945 & $1844-2790$ & 2082 & 2394 & $1582-2532$ \\
\hline Proteins (g/day) & $38-114$ & 69.9 & $50-80$ & $40-212$ & 72.5 & $46-92$ & $46-139$ & 65.4 & $50-80$ & $52-156$ & 75.6 & 58-103 \\
\hline Carbohydrates (g/day) & $171-247$ & 253.9 & $202-323$ & $182-262$ & 239.1 & $198-303$ & 209-302 & 254 & $204-329$ & $234-338$ & 307 & $229-383$ \\
\hline Lipids (g/day) & $42-59$ & 82.5 & $47-104$ & $45-63$ & 86.7 & $50-106$ & $52-72$ & 79.4 & $54-109$ & $58-81$ & 87.2 & $63-126$ \\
\hline Saturated fatty acids (g/day) & * & 25.6 & $16-38$ & * & 30.2 & $20-41$ & * & 24.9 & $16-35$ & * & 29.6 & $19-44$ \\
\hline Polyunsaturated fatty acids (g/day) & $9-19$ & 22.3 & $12-31$ & $10-20$ & 17.6 & $10-27$ & $12-23$ & 20.3 & $12-31$ & $13-26$ & 20.1 & $12-33$ \\
\hline Monounsaturated fatty acids ( $\mathrm{g} /$ day) & --- & 34.4 & $18-34$ & ---- & 30.8 & $18-37$ & --- & 26.2 & $18-36$ & & 29.6 & $21-42$ \\
\hline Cholesterol (mg/day) & * & 233.3 & $145-385$ & * & 252.9 & $133-397$ & * & 249.9 & $146-378$ & * & 292.7 & $190-432$ \\
\hline Fiber (g/day) & 25 & 8.7 & $5.4-11.9$ & 25 & 9.6 & $6-11$ & 26 & 8.7 & $6-12$ & $31-38$ & 10.6 & $8-14$ \\
\hline Calcium (mg/day) & 800 & 690.6 & $468-1006$ & 800 & 929.4 & $543-1231$ & 1100 & 647.7 & $407-1034$ & 1100 & 775.5 & $320-1115$ \\
\hline Vitamin A ( $\mu \mathrm{g} /$ day) & 275 & 478.6 & $291-801$ & 275 & 564.1 & $332-897$ & 420 & 411 & $246-712$ & 445 & 502.2 & $281-768$ \\
\hline $\operatorname{Iron}(\mathrm{mg} /$ day) & 4.1 & 12 & $9.5-17$ & 4.1 & 13.3 & $9-17$ & 5.7 & 12.7 & $10-16$ & 5.9 & 15.3 & $12-21$ \\
\hline Zinc (mg/day) & 4 & 9.8 & $6.5-13$ & 4 & 9.9 & $7-14$ & 7 & 9.2 & $7-12$ & 7 & 11.1 & $8-14$ \\
\hline Folate ( $\mu \mathrm{g} /$ day) & 160 & 496.5 & $343-626$ & 160 & 469.6 & $302-626$ & 250 & 509.5 & 299-706 & 250 & 631 & $381-857$ \\
\hline
\end{tabular}

* As low as possible while consuming a nutritionally adequate diet.

** Dietary reference intake by the Food and Nutrition Board. Institute of Medicine. National Academy of Sciences 2002-2005.

DRI: dietary reference intake. 
was the only one associated with a higher risk for obesity. Such association has been described in the bibliography.22

In addition, breakfast habit (at least 4 times per week) was observed to be a protective factor against both overweight and obesity; this has been demonstrated in different studies. ${ }^{23,24}$ In a systematic review, $\mathrm{H}$. Szajewska et al. described that children who did not have breakfast had a higher prevalence of overweight and obesity. Breakfast leads to regular eating habits, an adequate energy intake and a healthier food choice. It has been demonstrated that those who do not have breakfast tend to eat snacks high in fat and/or sugar at mid-morning. . $^{2-27}$

Regardless of the mentioned outcome measures, attending high school was also associated with a lower risk for excess weight. This may be explained by the eating habits and physical activity among high school children. ${ }^{28,29}$ In the bibliography no association has been established between the level of education and nutritional status; future studies are required to confirm such association and assess potential causes. In this regard, intake was higher than the DRI among children aged 6-8 years, with excess carbohydrate and fat consumption. This, together with the higher overweight and obesity prevalence related to primary school, suggests the influence of an obesogenic environment at this level.

No differences were observed in the prevalence of overweight or obesity in relation to age, sex, type of school (public/ private), maternal level of education or health coverage. Besides, no relationship was observed to other factors frequently associated with childhood nutritional status deficiencies, such as maternal age or having siblings younger than 5 years. ${ }^{6}$

A significant percentage of children, who mainly had severe obesity, had a WC $>$ P90. The increase in abdominal fat has been described as a risk factor for cardiovascular disease. The Bogalusa Heart Study, which was conducted in children aged 5-17 years, showed an association between central fat mass distribution measured by WC and abnormal triglyceride, low density lipoprotein (LDL), high density lipoprotein (HDL) and insulin levels. ${ }^{30}$ Hirschler et al. described, among Argentine schoolchildren aged 6-13 years, a prevalence of $\mathrm{WC}>\mathrm{P} 90$ of $0 \%$ (normal weight), $28.6 \%$ (overweight), and $87.5 \%$ (obesity), which was similar to our results that indicated $51 \%$ of children with a WC > P90 had at least one risk factor for cardiovascular disease. ${ }^{31}$

Once lab test data are analyzed, it is worth noting that a significant proportion of children had high cholesterol levels, even children with normal weight. Some studies refer that excess weight is associated with higher total cholesterol, LDL, and triglyceride levels and a lower HDL level. ${ }^{32}$

Based on our findings, determining triglyceride levels in obese children may help to detect approximately $40 \%$ of those who have an increase in this parameter. However, this excludes children with a normal weight, who probably have a greater representation of the genetic component and may be at risk for cardiovascular disease in the future.

Practically no vitamin or mineral deficiencies were observed.

The prevalence of anemia observed here was very low. This was expected in the studied age group. A lower prevalence of anemia has been described in schoolchildren compared to early childhood and adolescence ${ }^{8}$ given the improved adaptation between intake and nutritional requirements. Flour fortification as per Law no. 25630 (2002) may have contributed to a reduction in anemia in Argentina. However, specific studies are required to account for such finding.

The geographic distribution of children with excess weight was homogeneous across the District of General Pueyrredón. This demonstrates that such health problem is not exclusive of a specific sector or geographic area.

For dietary intake analysis, a 24-hour recall interview was used. The disadvantage of this tool is under-recording but it is the recommended instrument for population studies. For this reason, the study included food fact sheets, visual aids, and a standardized recall template with foods that are generally left out. Given the monotonous diet, all foods were included in the SARA software and analyzed.

Calcium intake was insufficient compared to the DRI, especially in the 9-14-year-old group, which may be explained by the increase in energy requirements and an inadequate dairy intake. ${ }^{33}$

Fiber intake was low in all age groups. Total fat intake was high at the expense of saturated fat; trans fat intake was twice the recommended values and dietary cholesterol was lower than recommended.

High blood cholesterol and triglyceride levels are consistent with excessiveintake of total, trans, and saturated fats, which may increase the risk for cardiovascular disease. ${ }^{21,34}$ 
This study has been conducted based on a reliable methodology for weight, height, waist, and biochemical parameter measurements. Some of the limitations of this study are the lack of data on outcome measures such as physical activity, screen time, and other factors related to excess weight.

\section{CONCLUSION}

The prevalence of excess weight was higher than what has been previously reported. The risk for obesity was higher among boys, and breakfast appeared as a protective factor against both overweight and obesity. In turn, a low-fiber and high-fat intake and high blood cholesterol and triglyceride levels have been reported, which altogether reveal that overnutrition is a prevalent public health problem.

\section{Acknowledgments}

We would like to thank Hugo Casarsa, M.D., Director of HIEMI "V. Tetamanti," for making the study possible.

The authorities of the Departments of Health and Education of the Municipality of General Pueyrredón and the PBA.

The Departments of Nursing Management and Teaching, Pediatrics, Laboratory, and Social Services, the Nutritional Support Division, the Areas of Diet and Diet Therapy, and the Head of the Outpatient Offices of HIEMI "V. Tetamanti" for their technical knowledge to carry out the internal review for the conceptual design.

The coordinators and teachers from the Certification in Nursing of the "Programa Eva Perón" conducted by the Ministry of Health of the PBA for helping us with the human resources.

The parents and children, for their selfless cooperation.

And the collaborators, for their knowledge and experience in developing the study (see Annex 4).

\section{REFERENCES}

1. Sánchez Echenique M. Aspectos epidemiológicos de la obesidad infantil. Rev Pediatr Aten Primaria2012;14(Supl 21):9-14.

2. World Health Organization. Global Strategy on Diet, Physical Activity and Health. Geneva: WHO, 2004. [Accessed on: May 19 $9^{\text {th }}, 2016$ ]. Available at: http:/ / www. who.int/dietphysicalactivity/goals/en/index.html

3. Ballesteros Arribas JM, Dal-Re Saavedra M, Pérez-Farinós $\mathrm{N}$, et al. La estrategia para la nutrición, actividad física y prevención de la obesidad (estrategia NAOS). Rev Esp Salud Pública 2007;81(5):443-9.

4. ArancetaBartrina J, Pérez Rodrigo C, Ribas Barba L, et al. Epidemiología y factores determinantes de la obesidad infantil y juvenil en España. Rev Pediatr Aten Primaria 2005;7(Supl 1):S13-20.

5. Grandy G, Weisstaub G, López de Romaña D. Deficiencia de hierro y zinc en niños. Rev Bol Ped 2010;49(1):25-31.

6. Calvo EB, Aguirre P. Crisis de la seguridad alimentaria en la Argentina y estado nutricional en una población vulnerable. Arch Argent Pediatr 2005;103(1):77-90.

7. Rivera JA, Barquera S, González-Cossio T, et al. Nutrition transition in Mexico and in other Latin American countries. Nutr Rev 2004;62(7 Pt 2):S149-57.

8. Encuesta Nacional de Nutrición y Salud, ENNyS. Documento de Resultados, 2007. Buenos Aires: Ministerio de Salud. [Accessed on: September 2012]. Available at: http://www.msal.gob.ar/images/stories/bes/ graficos / 0000000257cnt-a08-ennys-documento-deresultados-2007.pdf.

9. Ferrante D, Linetzky B, Ponce M, et al. Prevalencia de sobrepeso, obesidad, actividad física y tabaquismo en adolescentes argentinos: Encuestas Mundiales de Salud Escolar y de Tabaco en Jóvenes, 2007-2012. Arch Argent Pediatr 2014;112(6):496-503.

10. Kovalskys I, IndartRougier P, Amigo MP, et al. Ingesta alimentaria y evaluación antropométrica en niños escolares de Buenos Aires. Arch Argent Pediatr 2013;111(1):9-14.

11. Duelo Marcos M, Escribano Ceruelo E, Muñoz Velasco F. Obesidad. Rev Pediatr Aten Primaria 2009;11(Supl 16): 239-257.

12. Censo Nacional de Población, Hogares y Viviendas 2010. Instituto Nacional de Estadísticas y Censos. Argentina. [Accessed on: September 2012]. Available at: http:// www. indec.gob.ar/.

13. Benoist B, McLean E, Egli I, et al. Worldwideprevalence of anaemia 1993-2005. Base de datos mundial sobre la anemia delaOMS, Ginebra, Organización MundialdelaSalud, 2008. [Accessed on: August 23 ${ }^{\text {th }}$,2017]. Available at: http: / / apps. who.int/iris/bitstream/10665/43894/1/9789241596657_ eng.pdf.

14. Comité Nacional de Crecimiento y Desarrollo. Sociedad Argentina de Pediatría. Guía para la evaluación del crecimiento físico. 2013. [Accessed on: March 2013]. Availableat:http:/ / www.sap.org.ar/docs/publicaciones / libro_verde_sap_2013.pdf.

15. Comité Nacional de Nutrición. Guías de práctica clínica para la prevención, el diagnóstico y el tratamiento de la obesidad. Arch Argent Pediatr2011;109(3):198-203.

16. Gil Hernández A. Métodos para la evaluación de la ingesta de alimentos. In Tratado de Nutrición. Composición y calidad Nutritiva de los Alimentos. 2. ${ }^{a}$ ed. Madrid: Panamericana; 2010.p.594-6.

17. López BL, Longo NE, Carballido PM, et al. Validación del uso de modelos fotográficos para cuantificar el tamaño de las porciones de alimentos. Rev Chil Nutr 2006;33(3):480-7.

18. Patrones Internacionales de Crecimiento Infantil de la OMS. Buenos Aires: Ministerio de Salud. [Accessed on: September 2012]. Available at: http:/ / www.ms.gba.gov.ar/ sitios/maternoinfantil/files/2012/05/1-evaluacion_curvas_ final1.pdf.

19. Torresani ME. Manual Práctico de Dietoterapia del Niño. 1. ${ }^{\text {a }}$ Cátedra de Dietoterapia del Niño. Carrera de Nutrición de la Universidad de Buenos Aires. Buenos Aires: Akadia; 2011.

20. Dietary Reference Intakes (DRIs): Estimated Average Requeriments. [Accessed on: August 2017]. Available at: https: / / www.nap.edu/read/13050/ chapter/24\#1105.

21. Organización Mundial de la Salud. Dieta, Nutrición y Prevención de Enfermedades Crónicas: informe de una Consulta Mixta de Expertos OMS/FAO. Ginebra: OMS, 2003. Serie de Documentos Técnicos: 916. [Accessedon: 
March 12 $\left.{ }^{\text {th }}, 2014\right]$. Available at: www.who.int/nutrition/ publications/obesity/WHO_TRS_916_spa.pdf.

22. Goldberg L, FerranteD, KonfinoJ, et al. 2. ${ }^{a}$ Encuesta Mundial de Salud Escolar. Argentina 2012. Dirección de Promoción de la Salud y Control de Enfermedades No Transmisibles. Ministerio de Salud. Noviembre de 2013. [Accessedon: February 2014]. Available at:http:/ / www.msal.gob.ar/ent/ images/stories/vigilancia/pdf/2014-09_informe-EMSE-2012. pdf.

23. Berta E, Fugas V, Walz F, et al. Estado nutricional de escolares y su relación con el hábito y calidad del desayuno. Rev Chil Nutr 2015;42(1):45-52.

24. Henríquez Sánchez P, Doreste Alonso J, LaínezSevillanoP, et al. Prevalencia de obesidad y sobrepeso en adolescentes canarios: relación con el desayuno y la actividad física. Med Clin 2008;130(16):606-10.

25. Nicklas TA1, Reger C, Myers L, etal. Breakfast consumption with and without vitamin mineral supplement use favorably impacts daily nutrient intake of ninth-grade students. J Adolesc Health 2000;27(5):314-21.

26. Wyatt HR, Grunwald GK, Mosca CL, et al. Long-term weight loss and breakfast in subjects in the National Weight Control Registry. Obes Res 2002;10(2):78-82.

27. Szajewska H, Ruszczynski M. Systematic review demonstrating that breakfast consumption influences body weight outcomes in children and adolescents in Europe. Crit Rev Food Sci Nutr 2010;50(2):113-9.

28. Arriscado Alsina D, Muros Molina JJ, Zabala Díaz M, et al. Influencia del sexo y el tipo de escuela sobre los índices de sobrepeso y obesidad. Rev Pediatr Aten Primaria 2014;16(64):e139-46.

29. Poletti HO, Barrios L. Sobrepeso, obesidad, hábitos alimentarios, actividad física y uso del tiempo libre en escolares de Corrientes (Argentina). Rev Cubana Pediatr 2007;79(1). [Accessed on: October 14 $4^{\text {th }}, 2016$ ]. Available at: http:/ / scielo.sld.cu/scielo.php?script=sci_arttext\&pid=S003475312007000100006\&lng=es.

30. Freedman DS, Dietz WH, Srinivasan SR, et al. The relation of overweight to cardiovascular risk factors among children and adolescents: the Bogalusa Heart Study. Pediatrics 1999;103(6 Pt 1):1175-82.

31. Hirschler V, Delfino AM, Clemente G, et al. ¿Es la circunferencia de cintura un componente del síndrome metabólico en la infancia? Arch Argent Pediatr 2005;103(1):713.

32. Barja S, Barrios X, Arnaiz P, et al. Niveles de lípidos sanguíneos en escolares chilenos de 10 a 14 años de edad. Nutr Hosp 2013;28(3):719-25.

33. Zapata ME, Rovirosa A, Carmuega E. Estudio de patrones de consumo de lácteos y calcio en población argentina CESNI 2012. [Accessed on: October $13^{\text {th }}, 2016$ ]. Available at: http://www.cesni.org.ar/archivos/observatorio/ PAPGCL.pdf.

34. Ballesteros-Vásquez M, Valenzuela-Calvillo L, ArtalejoOchoa E, et al. Ácidos grasos trans: un análisis del efecto de su consumo en la salud humana, regulación del contenido en alimentos y alternativas para disminuirlos. Nutr Hosp 2012;27(1):54-64. 


\section{ANNEX 1}

Socioeconomic data collection sheet

This survey is part of the study on the nutritional status of schoolchildren from the District of GeneralPueyrredón. You should know that data will not be used for any other purposes and that children's names and data will not be disclosed in reports.

Please take 10 minutes to complete this survey. Thank you!

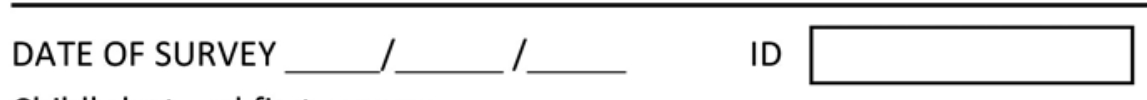

Child's last and first names:

ID no.:

Date of Birth: Sex: Male $\square$ Female $\square$

Place of birth:

Address:

School:

Grade:

1. What meals does the child usually have? (You may choose more than one) at least 4 times per week Breakfast L Lunch $\square$ Afternoon snack $\square$ Dinner $\square$

2. How old is the mother or caregiver? Age: _ years old.

3. Mother's or caregiver's level of education: (Choose only the highest level attained). None $\square$ Incomplete primary education $\square$ Incomplete secondary education $\square$ Incomplete university education
Complete primary education

Complete secondary education $\square$

Complete university education

4. Health coverage. What type(s) of health coverage or insurance does the child currently have? Social insurance / managed care organization $\square$

No coverage, receives care at a public primary health care center or hospital $\square$

5. Who else shares the household, including you?

\begin{tabular}{|l|c|}
\hline $\begin{array}{l}\text { Write down the relationship that each member of the household has with the child } \\
\text { (e.g., father or mother's spouse, mother, sibling, uncle, etc.) }\end{array}$ & AGE \\
\hline & \\
\hline & \\
\hline & \\
\hline & \\
\hline & \\
\hline
\end{tabular}




\section{ANNEX 2}

Anthropometric and biochemical assessment of nutritional status and dietary intake of children aged 6-14 years, Province of Buenos Aires, Argentina

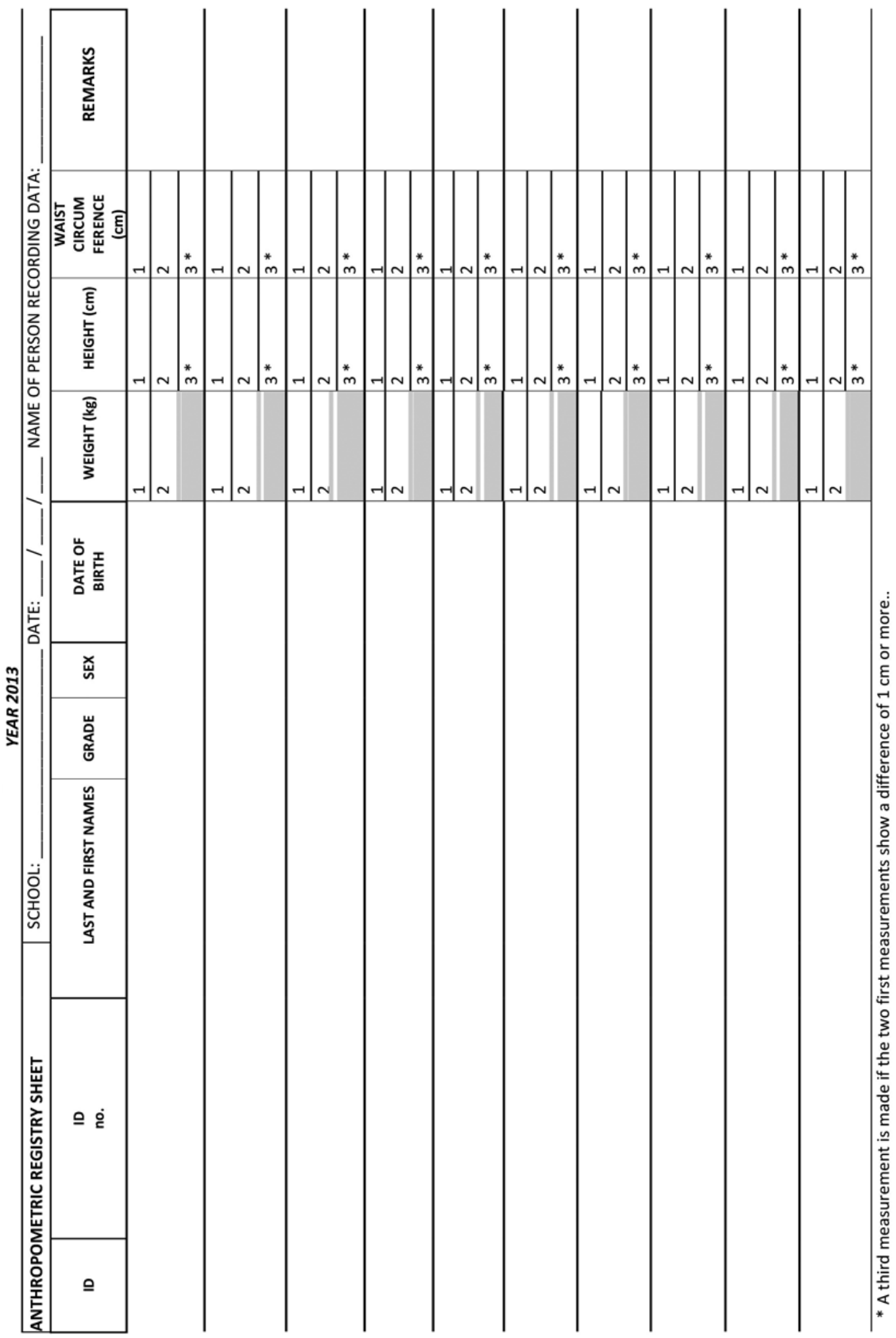




\section{ANNEX 3}

Distribution of children by nutritional status.

District of General Pueyrredón, Province of Buenos Aires, Argentina

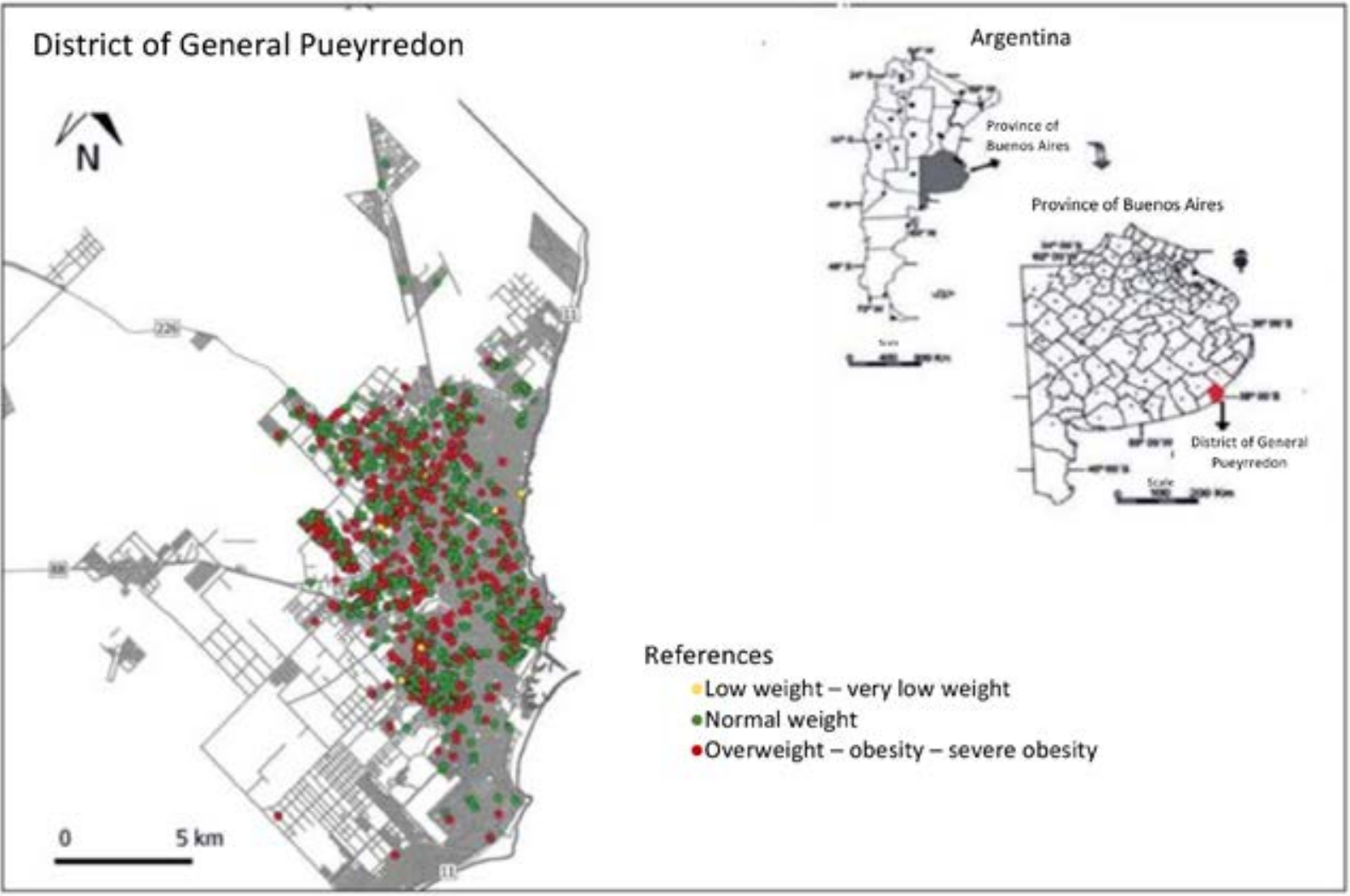




\section{ANNEX 4 \\ Collaborators}

Hospital Interzonal Especializado Materno Infantil “V. Tetamanti": Lic. Silvana Pinto, Nutr. Claudia Guridi, Lic. Carolina Echarri, Lic. Natalia García, Lic. Fernanda Paglione, Lic. Rocío Silva, Lic. Agustina Basso, Lic. Paola Buscaglia, Lic. Silvana Barragán, Lic. Malena Bouza, Dra. Pilar López, Dra. Ana Cabral, Dra. María Rossi, Lic. Cruz Costantini, Lic. Eugenia Epele, Lic. Adriana Mascolo, Lic. Daniela Ortega, Lic. Estefania Agostini, Lic. Estefanía André, Lic. Mercedes Pereira, Enf. Marta Rus, Enf. Sonia Martínez, Enf. Silvina Pose, Enf. Nieves Alanis, Aux. Enf. Carmen Monroy, Aux. Enf. Cristina Gómez, Enf. Almirón María, Enf. Fabián Vázquez, Enf. Laura Armúa, Dra. Nilda Parisi, Dra. Alina Guarino, Lic. Ana Algañaraz, Lic. Patricia Pastrana, Lic. Estela Todisco, Lic. Delia Fagoaga, Bioq. Paola Rolandi, Bioq. Valeria Cavallaro, Bioq. Magali Ramadori, Bioq. Carolina Noya, Téc. Marchena Flavia, Promotora Elvira Cisneros, Promotora Sandra Mascioli, Promotora Juliana Girard Riat,

Promotor Sergio Lombardo.

Department of Health of the Municipality of General Pueyrredón: Lic. Soledad Iacoponi, Dra. Iabranka Juhsic, Dr. Edgardo Marambio Catan, Lic. Estefanía Oteiza, Lic. Constanza Pagano, Lic. María Teresa Martínez.

Department of Education of the Municipality of General Pueyrredón: Dr. Martín Zemel. Universidad Nacional de Mar del Plata: MSC Mónica Tomas, Cart. Virginia Bernasconi, Cart. Marcelo Farenga.

Central Office for Region 19 of Private Education Management. Provincial Division of Private Management: Lic. Ana Carolina Di Alessio.

Universidad Nacional de La Plata: Dr. Marcelo Tavella.

Pediatric Research and Development Institute (Instituto de Desarrollo e Investigaciones Pediátricas (IDIP) “Prof. Dr. Fernando E. Viteri”: Dr. Horacio González, Bioq. Natalia Matamoros,

Bioq. Fernanda Santandreu, Bioq. Enrique Martins, Bioq. Ana Varea.

Ministry of Health of the Province of Buenos Aires: Lic. Nadia Attie, Lic. Paula Das Neves, Lic. Mónica López.

Universidad Nacional de Buenos Aires: Lic. Natalia Elorriaga.

Florida International University (EE. UU.): Dr. Nöel Barengo.

Mexican Public Health Institute: Dr. Juan Rivera.

Institute of Nutrition and Food Technology (Instituto de Nutrición y Tecnología de Alimentos de la Universidad de Chile (INTA): Dr. Ricardo Uauy. 